\title{
Clinical science \\ PREDICTIVE POTENTIAL OF THE MELD AND CHILD-TURCOTTE-PUGH II SCORES FOR SBP IN PATIENTS WITH CIRRHOSIS AND ASCITES
}

Fana Lichoska Josifoviki¹, Kalina Grivcheva Stardelova¹, Beti Todorovska¹, Magdalena Genadieva Dimitrova ${ }^{1}$ Lidija Petkovska², Meri Trajkovska

\footnotetext{
Republic of North Macedonia

University Clinic of Toxicology; Ss Cyril and Methodius University in Skopje, Faculty of Medicine, Republic of
}

North Macedonia

Citation: Lichoska Josifovikj F Grivcheva Stardelova K, Todorovska B,Genadieva Dimitrova M, Petkovska L, Trajkovska M. Predictive potential of the MELD and Child-furcotte-Pugh Il scores for SBP in patient with cirrhosis and ascites Predictive potential of the MELD and Child-Turcotte-Pugh II scores for SBP in patients with cirrhosis and ascites. Arch Pub Health 2021; 13 (2).1-9

doi.org/10.3889/aph.2021.6022

Key words: spontaneous bacterial peritonitis (SBP), Child-Turcotte-PughII score, MELD score

*Correspondence: Fana Lichoska Josifovikj. University Clinic of gastroenterohepatology, Skopje, Republic of North Macedonia, E-mail: fanili71@yahoo.com Received: 7-Jun-2021; Revised: 22-Sep-2021; Copyright: ${ }^{\circledR}$ 2021. Fana Lichoska Josifovikj, Kali na Grivcheva Stardelova, Beti Todorovska, Mag dalena Genadieva Dimitrova, Lidija Petkovska, Meri Trajkovska. This is an open-access article distributed under the terms of the Creative Commons Attribution License, which permits unrestricted use, distribution, and reproduction in any medium, provided the original author(s) and source are credited.

Competing Interests: The author have declared that no competing interests

\section{Abstract}

It is very important for patients with spontaneous bacterial peritonitis (SBP) to assess the length of survival and the risk of death, primarily because of the wide range of potential complications that can lead to multisystem organ failure and fatal outcome. The aim of this study was to determine the predictive potential of MELD and Child-Turcotte-Pugh II score for SBP in patients with cirrhosis and ascites. Material and methods: The study was designed as a prospectiveanalytical-observational and was conducted at the University Clinic for Gastroenterohepatoloog in Skopie for a period of one year. The study population included 70 hospitalized patients with established liver cirrhosis, regardless of etiology, divided into two groups, 35 patients with SBP and 35 non-SBP. Prognostic scores in patients with liver cirrhosis and ascites: MELD score, according to the formula: MELD = [(0.957 x Ln Creatinin) + (0.378 x Ln Bilirubin) + (1.12 x Ln INR) + (0.643) x 10]. The Child-Turcotte-Pugh II score includes 6 parameters: serum albumin and bilirubin, amount of ascites, degree of encephalopathy ( HE), prothrombin time (PT) and serum creatinine, and assessment of the degree of hepatic encephalopathy according to the West Haven criteria. Results: The average value of the MELD score in patients with SBP was $22.6 \pm 8.27$ and in non-SBP the average value was lower $-17.83 \pm 5.87$. According to the Mann-Whitney U test, the difference between the mean values was statistically significant for $\mathrm{p}<0.05 \mathrm{z}=2.41 ; \mathrm{p}=$ 0.015). A score of 30 to 39 was registered in $25.7 \%$ of patients with SBP, and only in $2.9 \%$ in non-SBP; the percentage difference was statistically significant for $p<0.05$ (Difference test, $p=0.0064$ ). Patients with SBP had an average ChildPugh score of $13.09 \pm 2.48$ or $100.0 \%$ C-class points. In patients with non-SBP, an average child-Pugh score of $9.63 \pm 1.62$ was recorded, or class B in $65.7 \%$ and class C in $34.3 \%$. The percentage difference was statistically significant for $\mathrm{p}<0.05$ Difference test, $p=0.000000$ ). According to the Mann-Whitney U test, the difference between the mean values was statistically significant for $\mathrm{p}<0.05(\mathrm{z}=-5.44 ; \mathrm{p}=0.00001)$. ROC analvsis indicated that the Child-Turcotte-Pugh II score contributed to the diagnosis of SBP - $90.7 \%(p=0.000)$ (excellent predictor), closer to the ideal value of 1.0 and above the worst value of 0.5 . ROC analysis indicated that the MELD score did not contribute to the diagnosis of SBP - 66.7\% ( $p=$ 0.017) (weak predictor), closer to the worst value of 0.5 . Conclusion:Our research confirmed that SBP occurs in patients with severe hepatic dysfunction calculated according to the CTP II score and MELD score. Mean value of the MELD score in patients with SBP was higher then in patients with non-SBP. On the other hand all patients with SBP had an average CTP II score, C-class points, while the largest percentage of patients with non-SBP were class B-class points. MELD score is a weak predictor of SBP. The best predictor for predicting SBP is the CTP II score (rank C).

\section{Клинички испитувања}

ПРЕДИКТИВЕНПОТЕНЦИЈАЛНА MELD И CHILD-TURCOTTE-PUGH II СКОРОТ ЗА СБПКАЈПАЦИЕНТИ СО ЦРНОДРОБНАЦИРОЗАИАСЦИТ

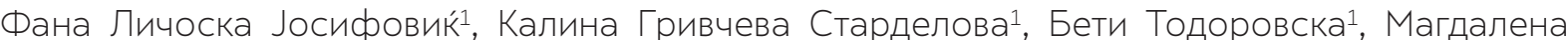
Генадиева Димитрова ${ }^{1}$, Лидија Петковска², Мери Трајковска

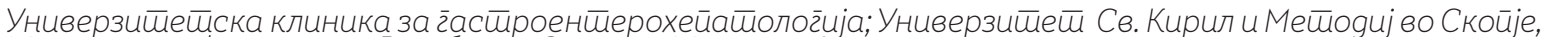
Меgииински факулиеш, Реиублика Северна макеgонија

Универзийейска клиника за йоксикологија; Универзиией Св. Кирил и Мейояиј во Скойје, Меgицински факулиеши, Рейублика Северна Макеgонија

Цитирање: Личоска Јосифовиќ Ф, Гривчева Старделова К, Тодровска Б, Генадиева Димитрова М, Петковска Л Трајковска М. ПредиктиII скорот за СБП кај пациенти со црнодробна цироза и асцит. Арх. J. Здравје 2021;13(2) 1-9

doi.org/10.3889/aph.2021.6022

Клучни зборови: спонтан бактериски перитонитис (СБП), Child-Turcotte-Pugh II скор, MELD скор *Кореспонденција: Фана Личоска Јосифовик. Универзитетска клиника за гастроентерохепатологија; Универзитет Св. Кирил и Методиј во Скопје Медицинсии факултет, Република Северна Македонија

E-mail: fanili71@yahoo.com

Примено: 7-jvн-2021; Ревидирано: 22-сеп-2021; Прифатено: 30-сеп-2021; 0бјавено: 12-ное-2021 Печатарски права: ${ }^{\circledR 2021}$ Фана Личоска Јосифовиќ, Калина Гривчева Старделова, Бети Тодоровска, Магдалена Генадиева Димитрова, Лидија Петковска, Мери Трајковска. Оваа статија е со отворен пристап дистрибуирана по ссловите на нелокализирана лиценца, која овоз можува неограничена употреба, дистрибуција и репродукција на било кој медиум, доколку се цитират оригиналниот ите) автор и и изворот. Конкурентски интереси: Авторот изјавува дека нема конкурентски интереси.

\section{Извадок}

Поради широкиот спектар на потенцијални компликации кои може да доведат до мултисистемско органско попуштање и смрт, многу е важно кај пациентите со спонтан бактериски перитонитис (СБП) да се направи проценка на должината на преживување и ризикот од смртен исход. Целта на трудот беше да се одреди препиктивниот потенциіал на MELD и Child-Turcotte-Pugh II скорот (CTP II) за СБП кај пациентите со црнодробна цироза и асцит. Материјал и методи: Студијата беше дизајнирана како проспективно-аналитичко-опсервациска и се спроведе на Универзитетската клиника за гастроентерохепатологија во Скопје во период од една година. Студиска популација беа хоспитализирани пациенти со етаблирана црнодробна цироза, без оглед на етиологијата, вкупно 70 пациенти, поделени во две групи, 35 пациенти со СБП и 35 без СБП. Прогностички скорови кај пациенти со црнодробна цироза и асцит: MELD скор, според формулата: MELD = [(0,957 x Ln Creatinin $)+(0,378$ x Ln Bilirubin) + (1,12 x Ln INR) + (0,643) x 10]. CTП II скор вклучvва 6 параметри: албумин и билирубин во серум, количина на асцит, степен на енцефалопатија, протромбинско време (ПВ) и креатинин во серум, а проценка на степенот на хепатална енцефалопатија(HE) co West-Haven-овите критериуми. Резултати: Просечната вредност на MELD скорот кај пациентите со СБП изнесуваше 22,6 88,27 а кај оние без СБП просечната вредност беше пониска и изнесуваше 1783+5,87. Според Mann-Whitney U тестот разликата помеѓ просечните вредности беше статистички сигнификантна за $p<0,05$ ( $\mathrm{z}=2,41 ; \mathrm{p}=0,015)$. Вредност на скорот од 30 до 39 беше регистрирана кај 25,7\% од пациентите со СБП, а само кај 2,9\% од оние без СБП; процентуалната разлика беше статистички сигнификантна за p $<0,05$ (Difference тест, $p=0,0064$ ).Кај пациентите со СБП беше регистрирана просечна вредност на CTP II скорот од 13,09+2,48 или во поени 100,0\%, класа С. Кајпациентите без СБП беше регистрирана просечна вредност на СТP II скорот од 9,63 1 1,62 или класа В кај 65,7\% и класа С кај 34,3\%. Процентуалната разлика беше статистички сигнификантна за p<0,05 (Difference тест, p=0,000000). Според Mann-Whitney U тестот, разликата помеѓу просечните вредности беше статистички сигнификантна за p<0,05 (z =-5,44; p=0,00001).ROC-анализата покажа дека СТP II скорот придонесува за дијагностицирање на СБП - 90,7\% (p = 0,000) (одличен предиктор), поблизу до идеалната вредност од 1,0 и над најлошата вредност од 0,5 ROC-әнализата покажа дека MEID скорот не придонесүва 32 пијагностицирање на СБП со 66,7\% ( к:Нашето истражување потврди дека СБП се јавува кај пациенти со тешка хепатална дисфункција пресметана според CTP II и MELD скорот. Средната вредност на MELD скорот кај пациенти со СБП беше поголема отколку кај пациенти со не-СБП. Од друга страна, сите пациенти со СБП имаа просечна вредност на СТР II, С-класа, додека наіголем процент од пациентите со не-СБП беа B-класа. MELD скорот е слаб предиктор за СБП. Наідобар предиктор за предвидување на СБП е СТР ІІ (ранг С) скор. 


\section{Introduction}

It is very important for patients with spontaneous bacterial peritonitis (SBP) to assess the length of survival and the risk of death, primarily because of the wide range of potential complications that can lead to multisystem organ failure and fatal outcome. Prognostic scores, expressed in numerical values, assess the severity of the current condition using mathematical models and are especially important in transplant medicine (priority for hepatic transplantation).

The Child-Turcotte-Pugh score (CTP score) includes five parameters: albumin and bilirubin in the blood, amount of ascites, degree of hepatic encephalopathy, and prothrombin time $(\mathrm{PT})^{1-3}$. The last three decades have shown that this score is a good prognostic indicator for the survival of patients with alcoholic and posthepatic cirrhosis, primary biliary cirrhosis, primary sclerosing cholangitis, and Budd-Chiari syndrome ${ }^{4-7}$. According to critics, the disadvantage of this score is the inaccuracy that can occur due to the two descriptive parameters: quantification of ascites and hepatic encephalopathy (HE), which values depend on the experience and personal assessment of the examiner. They also stressed that this score is insufficiently accurate in distinguishing the true clinical significance of category $\mathrm{C}$, not including renal laboratory parameters in the evaluation of patients, primarily due to the development of hepatorenal syndrome in patients with terminal disease as a major factor for lethal outcome $^{8,9}$.

In order to overcome these problems, Angermayr et al.10performed remodeling of the CTP score by including a new parameter, serum creatinine lev- el. According to this score, numerical values (points) are added to the baseline values of the CTP score: 0 points for a creatinine value less than 114.92 nolmol / L, 2 points for a creatinine value of 114.92-159.12 $\mathrm{molmol} / \mathrm{L}$ and 4 for a creatinine value greater than $159.12 \mu o l m o l$ / L. Analyses showed that the remodeled CTP score was better than the baseline CTP score in predicting HP, but with the same prognostic value in predicting other complications as the baseline CTP score. The significance of the CTP score in terms of survival has been well studied and its grades are: A (5-7 points) - with a median annual survival of 95\%, B (7-9 points) - with a median annual survival of $80 \%$ and $C$ (10-15 points) - with a median annual survival of $45 \%{ }^{11}$.

The MELD Score (Model for End Stage Liver Disease) first appeared in 1999 to assess survival in patients with transjugated portosystem shunt $(\text { TIPS })^{12}$. In the following years the MELD score proved to be a good predictor of short-term survival, a major mortality predictor regardless of etiology and has been officially accepted for assessment of patients undergoing potential cadaveric transplantation $^{13,14}$. In the United States and Europe, this model is used to predict the three-month survival of patients waiting on a liver transplant list ${ }^{15-17}$. According to the original formula, the MELD score is a mathematical formula that includes: serum bilirubin, serum creatinine and INR.MELD $=9.57 \mathrm{x} \ln ($ creatinine $\mathrm{mg} / \mathrm{dl})+3.78 \mathrm{x}$ $\ln$ (bilirubin $\mathrm{mg} / \mathrm{dl})+11,2 \mathrm{x} \ln (\mathrm{INR})$ +6.43 .

Aim of the paper was to determine the predictive potential of MELD and CTP II score for SBP in patients with cirrhosis and ascites. 


\section{Material and methods}

The study was designed as a prospective-analytical-observational and was conducted at the University Clinic for Gastroenterohepatology in Skopje for a period of one year. The study population included hospitalized patients with established liver cirrhosis, regardless of etiology; 70 patients, divided into two groups, 35 patients with SBP and 35 non-SBP, with similar demographic characteristics as the SBP group with sterile ascites, in which all variables were examined. as in the study group. The selection of patients who were included in the study was conducted according to pre-determined inclusion and exclusion criteria. Inclusion criteria: patients with cirrhosis of the liver regardless of etiology, age $>18-70$ years. Exclusion criteria: age $<18$ years, acute liver failure, recent abdominal surgery $(<3$ months), infectious pleural effusion, peritoneal carcinomatosis, haemorrhagic ascites (of any origin), hepatocellular carcinoma, immunocompromised patients and those receiving antibiotics for at least 2 weeks prior to enrollment, patients taking nonsteroidal anti-inflammatory drugs (NSAIDs), oral contraceptives and anticoagulants.

The study included patients with previously signed informed consent (for the examinations they underwent). Polymorphonuclear cells (PMNC) number was determined directly from the non-centrifuged part of the ascites. $3 \mathrm{ml}$ of fluid was placed in an EDTA test tube to assess the total number of cells and PMN cells, counting by using the Sysmex KxN 21 automatic cell counter-model. Paracentesis was performed under aseptic conditions in a patient placed in a supine position and puncture was made in the left or right lower abdomen quadrant, with ultrasound imaging (no patient had complications associated with diagnostic paracentesis). All samples for diagnostic testing were immediately sent to the Central Clinical Laboratory. Five mL of ascites was used for automatic counting of PMNK, and at the same time for the needs of biochemical analysis of blood venipuncture of $10 \mathrm{~mL}$ of blood was performed. By ultrasonographic examination of the abdomen (ultrasonographic apparatus Samsung Acuson x 300, CH5-2 MHz convex probe), morphological and circulatory disorders within liver cirrhosis were noted. Quantification of ascites was performed by US examination: no ascites, minimum amount of ascites, medium amount of ascites and large amount of ascites. Prognostic scores in patients with liver cirrhosis and ascites: MELD score, according to the formula: MELD $=[(0.957 \times$ Ln Creatinin $)+(0.378 \times$ Ln Bilirubin $)+(1.12 x$ Ln INR) + (0.643) x 10]. The CTP II score includes 6 parameters: serum albumin and bilirubin, amount of ascites, degree of encephalopathy, PV and serum creatinine, and assessment of the degree of hepatic encephalopathy according to the West Haven criteria. Quantification of the degree of hepatic encephalopathy was performed using the West-Haven scale: zero degree (minimal encephalopathy without detectable changes in personality, behavior, memory, concentration, intellectual functions and coordination and asterixis absent). Frst degree (hypersomnia, insomnia, changes in affect, euphoria, depression, irritability, confusion, slowness), second degree (lethargy, apathy, disorientation in time, visible asterixis, visible change in personality), third degree (somnolence, disorientation in time and space, amnesia, more severe confusion, unrelated speech), fourth 
degree: coma without response to external stimuli.

Criteria for spontaneous bacterial peritonitis: clinical picture, PMNC number in ascites $\geq 250 / 1 \mathrm{~mL}$ and / or PMNC number $<250$ / in $1 \mathrm{~mL}$ ascites fluid, with one bacterial species isolated in microbial culture (CNNA). After prior acquaintance with the structure, content and purpose of the study, as a condition for participation in it, the patients signed the offered informed consent. The study protocol was in line with the ethical principles of the Helsinki Declaration. The protocol and informed consent were submitted for consideration and approved by the Ethics Commission of the Faculty of Medicine at the Ss. Cyril and Methodius Universityin
Skopje. The collected data was processed using the statistical program SPSS 20 and Statistica for Windows, version10.

\section{Results}

The mean value of the MELD score in patients with SBP was $22.6 \pm$ 8.27 and in non-SBP the mean value was lower at $17.83 \pm 5.87$. According to the Mann-Whitney U test, the difference between the mean values was statistically significant for $\mathrm{p}<0.05 \mathrm{z}=$ $2.41 ; p=0.015)$. A score of 30 to 39 was registered in $25.7 \%$ of patients with SBP, and only in $2.9 \%$ of non-SBP; the percentage difference was statistically significant for $\mathrm{p}<0.05$ (Difference test, $p=0.0064)($ Tab. 1).

Table 1. The prevalence of MELD score in both groups

\begin{tabular}{|c|c|c|c|c|}
\hline \multirow[t]{2}{*}{ MELDscore } & \multicolumn{2}{|c|}{ SBP } & \multicolumn{2}{|c|}{ Non-SBP } \\
\hline & $\mathrm{N}$ & $\%$ & број & $\%$ \\
\hline$>40$ & 0 & & 0 & \\
\hline $30-39$ & 9 & 25.7 & 1 & 2.9 \\
\hline $20-29$ & 12 & 34.3 & 13 & 37.1 \\
\hline $10-19$ & 13 & 37.1 & 17 & 48.6 \\
\hline$<9$ & 1 & 2.9 & 4 & 11.4 \\
\hline total & 35 & 100.0 & 35 & 100.0 \\
\hline
\end{tabular}

Patients with SBP had an average CTP II score of $13.09 \pm 2.48$ or $100.0 \%$ C-class points. In patients with nonSBP, an average CTP II score of $9.63 \pm$ 1.62 was recorded, or class B in $65.7 \%$ and class $\mathrm{C}$ in $34.3 \%$. The percentage difference was statistically signifi- cant for $\mathrm{p}<0.05$ (Difference test, $\mathrm{p}=$ 0.000000 ) (Tab. 2). According to the Mann-Whitney U test, the difference between the mean values was statistically significant for $\mathrm{p}<0.05(\mathrm{z}=-5.44$; $p=0.00001)$. 
Table 2. The prevalence of CTP II score in both groups

\begin{tabular}{|c|c|c|c|c|c|}
\hline \multirow[t]{2}{*}{ points } & \multirow[t]{2}{*}{ class } & \multicolumn{2}{|c|}{ SBP } & \multicolumn{2}{|c|}{ Non-SBP } \\
\hline & & $\mathrm{N}$ & $\%$ & број & $\%$ \\
\hline $5-6$ & A & & & & \\
\hline $7-9$ & B & & & 23 & 65.7 \\
\hline 10-15 & $\mathrm{C}$ & 35 & 100.0 & 12 & 34.3 \\
\hline
\end{tabular}

ROC analysis indicated that the CTP predictor), closer to the ideal value of II score contributed to the diagnosis 1.0 and above the worst value of 0.5 of SBP $-90.7 \%(p=0.000)$ (excellent (Fig. 1).

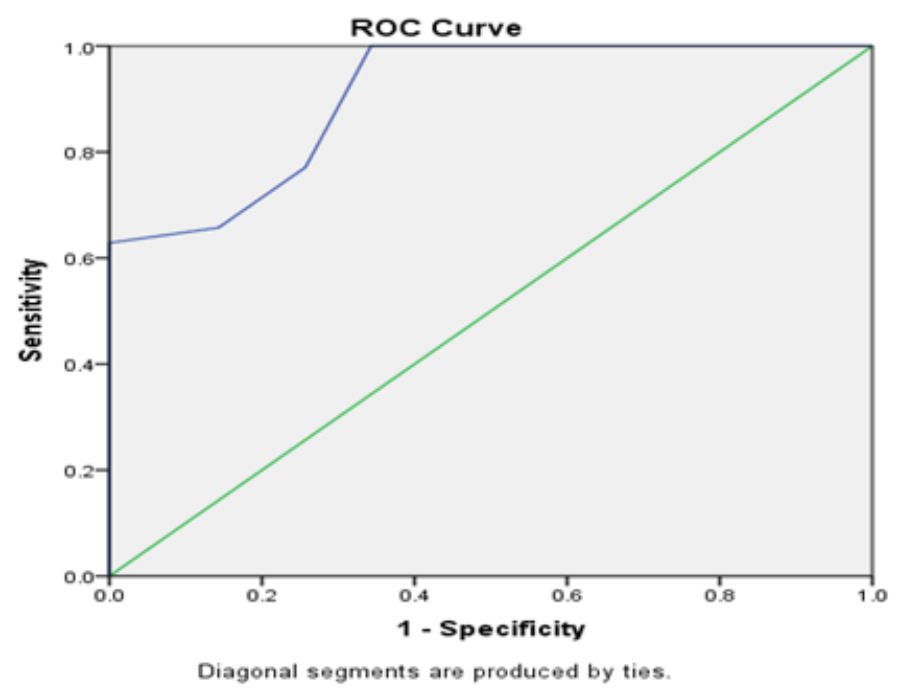

Figure 1. ROC curve of CTP II score as a predictor for SBP

ROC analysis indicated that the MELD score did not contribute to the diagnosis of SBP with $66.7 \%$ ( $p=0.017$ ) (weak predictor), closer to the worst value of 0.5 (Fig. 2).

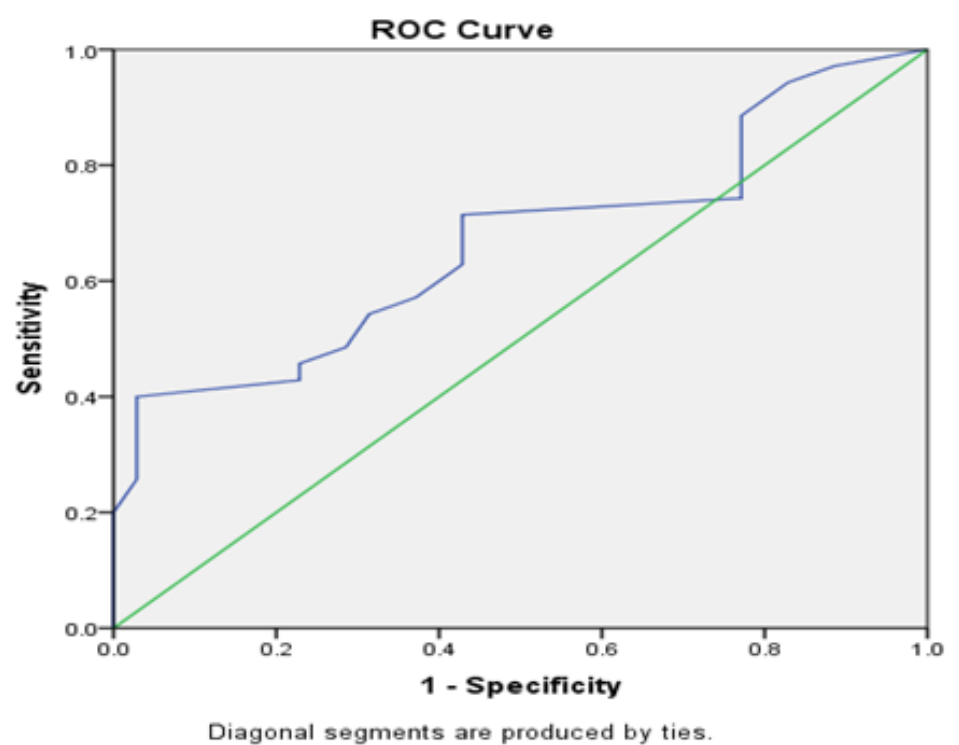

Figure 2. ROC curve of MELD score as a predictor for SBP 


\section{Discussion}

The study of prognostic scores in the prediction and prognosis of individual complications of cirrhosis has confirmed their role in clinical practice and simplified access to this vulnerable group of patients. Thanopoulou et al. ${ }^{17}$ in their study focused on these clinically simple prognostic assessors. The authors encouraged the introduction of diagnostic paracentesis into the daily routine of all patients with ascites, with the aim of early diagnosis of asymptomatic forms of SBP. Significant prognostic factors for SBP in this study were: the number of PMNCs in ascites, serum bilirubin levels, and renal function status, and the recurrence of SBP depended on the value of the CTP score.

In our study all patients with SBP were categorized in class $\mathrm{C}$ on CTP II score $(100.0 \%)$ with a mean value of $13.09 \pm 2.40$, while in the non-SBP group the mean value was $9.63 \pm 1.26$ (B score: $65.7 \%$ and C score: $34.3 \%$ (p $=0.000000)$. The mean values of the MELD score in patients with SBP were $22.60 \pm 8.27$ versus $17.83 \pm 5.87$ in patients with non-SBP $(\mathrm{p}=0.0064)$. The analysis of the results of this segment by our judge can be based on the advantage of the CTP II score over the MELD score in the group of patients with SBP. CTP II contains a calculated amount of ascites and creatinine in serum, and has been shown to be the best predictor of SBP, in contrast to the MELD score which has not been shown to be a good predictor of this condition.According to the ROC analysis, the CTP II score is an excellent predictor of SBP $(90.7 \%)(p=0.000)$.

Thus, our study confirmed that the MELD score requires additional data on the amount of ascites to become an accurate predictor of ascites-re- lated conditions and ascites consequences. The prevalence of SBP is higher in patients with severe liver cirrhosis calculated according to the CTP score (class C from $50.3 \%$ to $100 \%$ ), presented in several studies ${ }^{18-}$ 23. The prospective Haddad 24 study included 148 asymptomatic patients with cirrhosis and refractory ascites. SBP was detected in only 23 patients (3.3\%), confirming the low prevalence of SBP in asymptomatic patients with cirrhosis of the liver, while the incidence of SBP was not associated with the severity of liver disease assessed by MELD. Patients on the transplant list have a lower rate of SBP and have significantly higher MELD scores, so the development of SBP is not related to the value of the MELD score but to clinical status and refractory ascites and the need for repetitive paracentesis.

One of the reasons for the low rate of SBP is explained by the fact that in today's conditions, thanks to the appropriate equipment and human resources necessary for proper and successful paracentesis, errors are very rare. Also Zhang et al. ${ }^{25}$, who treated a larger population of patients, did not find any score that would be convincing in the SBP prediction. The study only confirmed that patients with SBP had a higher risk of death than non-SBP. In our analysis, the MELD score proved to be a weak predictor for diagnosing SBP with 66.7\% $(p=0.017)$, but several other studies have emphasized its predictive value. Namely, according to them, with each increase of the MELD score, the risk for SBP increases.

Thus, according to Obstein KL. 26 that risk increases by $11 \%$, and according to Gayatri AA. 27by 30.6\%. Some authors even suggested that patients with moderate liver cirrhosis 
and ascites with MELD score 20 start a preventive antibiotic treatment 28 . Desai et al. 29 focused their research on finding the ideal score that would be predictive of persistent STD. The results showed that the MELD score with values greater than 25 had the highest predictive power compared to other prognostic scores.

\section{Conclusion}

Our research confirmed that SBP occurs in patients with severe hepatic dysfunction calculated according to the CTP II score and MELD score. Mean value of the MELD score in patients with SBP was higher then in patients with non-SBP. On the other hand all patients with SBP had an average CTP II score, C-class points, while the largest percentage of patients with non-SBP were class Bclass points. MELD score is a weak predictor of SBP. The best predictor for predicting SBP is the CTP II score (rank C).

\section{References}

1. Child C, Turcotte J. The liver and portal hypertension. In:Child CI, ed. Surgery and Portal Hypertension. Philadelphia,USA: W. B. Saunders, 1964: 50-8.

2. Pugh R, Murray-lyon I, Dawson J. Transection of the oesophagus for bleeding oesophageal varices. $\mathrm{Br} \mathrm{J}$ Surg1973; 60: 646-9.

3. Vorobioff J, Groszmann RJ, Picabea E, et al. Prognostic value of hepatic venous pressure gradient measurements in alcoholic cirrhosis: A 10year prospective study. Gastroenterology 1996;111(3):701-9.

4. Shah DN, Ventura-Cots M, Abral- des JG, et al. Alcohol-related liver disease is rarely detected at early stages compared with liver diseases of other etiologies worldwide. Clin Gastroenterol Hepatol 2019;17(11):2320-2329.

5. Planas R, Balleste B, Alvarez MA, Rivera M, Montoliu S, Galeras JA, et al. Natural history of decompensated hepatitis C virus-related cirrhosis. A study of 200 patients. J Hepatol 2004;40:823-30.

6. Shetty K, Rybicki L, Carey WD. The Child-Pugh classification as a prognostic indicator for survival in primary sclerosing cholangitis. Hepatology 1997;25:1049-53.

7. Zeitoun G, Escolano S, Hadengue A, et al. Outcome of Budd-Chiari syndrome: a multivariate analysis of factors related to survival including surgical portosystemic shunting. Hepatology 1999;30:84-9.

8. Wiesner RH, McDiarmid SV, Kamath PS, Edwards EB, Malinchoc $\mathrm{M}$, Kremers WK, et al. MELD and PELD: application on survival models to liver allocation. Liver Transpl 2001;7:567-80.

9. Dharel N, Bajaj JS. Definition and nomenclature of hepatic encephalopathy. J Clin Exp Hepatol 2015 Mar;5(Suppl 1):S37-41

10. Angermayr B, Cejna M, Karnel F,et al. Child-Pugh versus MELD score in predicting survival in patients undergoingtransjugular intrahepatic portosystemic shunt. Gut 2003; 52:879-85.

11. Samiullah S, Qasim R, Khalid S, Hussain BG, Mukhtair J, Akbar Y. Evaluation of creatininemodified Chid-Pugh skore for predicting short-term prognosis of patients 
with decompensated cirrhosis of liver as compare to original ChildPugh score. J Ayub Med Coll Abbottabad 2009;21(2):64-7.

12. Malinchoc M, Kamath PS, Gordon FD, Peine CJ, Rank J, ter Borg PC. A model to predict poor survival in patients undergoing transjugular portosystemic intrahepatic portosystemic shunts. Hepatology 2000;31:864-71.

13. Said A, Williams J, Holden J, Remington P, Gangnon R, Musat A, Lucey MR. Model of endstage liver disease score predicts mortality across a broad spectrum of liver disease. J Hepatol 2004;40:897-903.

14. Martin AP, Bartels M, Hauss J, Fangmann J. Overview of the MELD score and the UNOS adult liver allocation system. Transplant Proc 2007;39:3169-74.

15. Ravaioli M, Grazi GL, Ballardini G, et al. Liver transplantation with the Meld system: a prospective study from a single European center. Am J Transplant 2006;6:1572-7.

16. Schepke M, Roth F, Fimmers R, Brensing KA, Sudhop T, Schild $\mathrm{HH}$, Sauerbruch T. Comparison of MELD, Child-Pugh, and Emory model for the prediction of survival in patients undergoing transjugular intrahepatic portosystemic shunting. Am J Gastroenterol 2003;98: 1167-74.

17. Wiesner RH, McDiarmid SV, Kamath PS, Edwards EB, Malinchoc M, Kremers WK, et al. MELD and PELD: application on survival models to liver allocation. Liver Transpl 2001;7:567-80.

18. Thanopoulou AC, Koskinas JS, Hadziyannis SJ. Spontaneous bacte- rial peritonitis (SBP): clinical, laboratory, and prognostic features. A single-center experience. Eur J Intern Med 2002;13(3):194-8.

19. Oladimeji AA, Temi AP, Adekunle AE, Taiwo RH, Ayokunle DS. Prevalence of spontaneous bacterial peritonitis in liver cirrhosis with ascites. Pan Afr Med J 2013;15:128.

20. Coral G, Mattos AA, Damo DF, Viégas AC. Prevalence and prognosis of spontaneous bacterial peritonitis. Experience in patients from a general hospital in Porto Alegre, RS, Brazil (1991-2000). Arq Gastroenterol 2002; 39(3):158-62. 1.

21. Such J, Runyon BA. Spontaneous bacterial peritonitis. Clin Infect Dis 1998;27:669-74.

22. Heo J, Seo YS, Yim HJ, et al. Clinical features and prognosis of spontaneous bacterial peritonitis in korean patients with liver cirrhosis: a multicenter retrospective study. Gut Liver 2009;3(3): 197-204.

23. Kasztelan-Szczerbinska B, Slomka M, Celinski K, et al. Prevalence of spontaneous bacterial peritonitis in asymptomatic inpatients with decompensated liver cirrhosis - a pilot study. Adv Med Sci 2011;56(1):137.

24. Haddad L, Conte TM, Ducatti L, et al. MELD Score is not related to spontaneous bacterial peritonitis. Gastroenterol Res Pract 2015;2015:270456.

25. Zhang QB, Chen YT, Lion GD, Qian CC, Chen SJ, Huang KH. A combination of models for end-stage liver disease and cirrhosis-related complications to predict the prognosis of liver cirrhosis. Clin Res Hepatol Gastroenterol 2012;36:583-9.

26. Obstein KL, Campbell MS, Reddy RK, 
et al. Association between model for end-stage liver disease and spontaneous bacterial peritonitis. Am J Gastroenterol 2007;102(12):2732-6.

27. Gayatri AA, Suryadharma IG, Purwadi N, Wibawa D. The relationship between a model of end stage liver disease score (MELD score) and the occurrence of spontaneous bacterial peritonitis in liver cirrhotic patients. Acta Medica Indonesiana 2007; 39(2): 75-78.

28. Oey RC, van Buuren HR, de Jong DM, et al. Bacterascites: A study of clinical features, microbiological findings, and clinical significance. Liver Int 2018;38(12):2199-2209.

29. Desai AP, Reau N, Reddy G, et al. Persistant spontaneous bacterial peritonitis: a common complications in patients with spontaneous bacterial peritonitis and a high score in the model for end-stage liver disease. Ther Adv Gastroenterol 2010;5(5):275-83. 